\title{
Phytotherapy and oncology. A short review
}

\author{
A Sannia* \\ Società Italiana di Medicina Naturale (SIMN), Italy
}

The problem of the relationship with Complementary Medicine, in this historical moment, is very much conditioned by the debate around the evidence and the methodologies with which they are obtained. As we know, in oncology, treatment and research are essentially focused on cancer. In complementary medicine, the disease is seen in a more dynamic way as the clash between the cancer disease and the body's antipathogenic resistance factors. This simple change of view allows for several operations. First of all, it becomes possible to try to trace personalized therapy paths for cancer disease for each patient because, if on the one hand it is clear that we must fight the tumor, on the other it is no less important to support the organism in its battle which is a psychological, immunological and endocrinological battle. Secondly, if the resources for this clash are to be sought in a $360^{\circ}$ vision of man, it is clear that the promotion of a patient's quality of life, even during illness, is no less important than the search for health, which can be connected to the first in a much closer way than is usually believed. And often there may be valuable resources in the patient to mobilize for the pursuit of healing. Last but not least, the body's ability to resist therapy, for example to chemotherapy cycles, can be improved by producing a true synergy between herbal remedies and the usual conventional therapies. The phytotherapy of the two lines of treatment (1- fight cancer, 2- support the body) has above all developed the second with better success, which is closely connected with the so-called palliative therapies.

The main areas that phytotherapy can address in the field of oncological palliative care are:

1) asthenia and weakness

2) psycho-organic wasting.

3) pain in general.

4) nausea and vomiting.

5) radiation therapy dermatitis.

6) anxious depressive syndrome and sleep disturbances.

7) immunosuppression.

8) gastrointestinal disorders.

Although in the practice of phytotherapy the experience related to supportive therapy to chemotherapy or other anticancer therapies is prevalent, this does not mean that there are numerous lines of research aimed at highlighting possible anticancer activities by herbs traditionally used for purposes, often, also very different. Among the main ones we can mention:

\section{Curcuma longa (Curcuma)}

The Curcuma rhizome, which contains a mixture of triterpene saponins, called curcuminoids, has been shown to have chemopreventive and growth inhibiting activities against various tumor cell lines. It seems to induce apoptosis in cancer cells and can inhibit angiogenesis. Curcumin also inhibits the activation of NF-KappaB and the expression of genes regulated by NF-KappaB itself. It has numerous in vitro and animal studies regarding its antineoplastic action, which seems mainly aimed at cancers of the digestive system and in particular those of the large intestine and liver. Interesting clinical data are also available for prostatic, mammary, uterine, cutaneous neoplasms, glioblastomas and leukemias [1-13].

\section{Vitis vinifera (Red grapes)}

Resveratrol and the polyphenols present in this drug are capable of inducing cellular apoptosis, especially through a p53 mediated mechanism. Resveratrol is able to hinder the growth of numerous types of cancer cells (lymphoid and myeloid carcinomas, multiple myeloma, carcinoma of the breast, prostate, stomach, colon, pancreas, thyroid, melanoma, squamous carcinoma of the head and of the neck, ovarian cancer and cervical cancer. It causes in these cells the arrest of cell cycle progression with the activation of caspases. Resveratrol is capable of inhibiting the activation of nuclear transcription factors such as NFKappaB, AP-1 and Egr-1 and to inhibit protein kinases. It also causes a down-regulation of the products of certain genes such as COX2, 5-LOX, VEGF, Il1, IL6, IL8, AR and PSA. In vitro studies indicate that the polyphenols of wine can reduce angiogenesis by hindering the proliferation and migration of endothelial cells and smooth muscle cells and the expression of two fundamental proangiogenic factors. Resveratrol enhances the apoptotic effects of some chemotherapy drugs and of the radiation therapy. Toxicology data indicate that it appears to be reasonably safe in humans and has very few side effects [14-21].

\section{Glycine max (Soy)}

This plant and its extracts rich in isoflavones have very interesting properties in the oncology sector. Genistein reduces the formation of new blood vessels. Neoplasms, on the other hand, need a lot of blood, so this anti-angiogenic effect of phytoestrogens can help explain their anticancer effect. Tyrosine kinase inhibitors are known to have antineoplastic effects, but their toxicity is quite significant. Instead genistein, which is a natural inhibitor of this enzyme present in soy flour in quantities of 1-2 $\mathrm{mg} / \mathrm{g}$. of flour, does not appear to have toxic effects even at a dose of $200 \mathrm{mg} / \mathrm{day}$, and appears to have a protective effect against breast, colon, prostate and female genital tract

${ }^{\star}$ Correspondence to: A Sannia, Società Italiana di Medicina Naturale (SIMN), Milano, Italy, E-mail: antosannia@libero.it

Received: February 02, 2021; Accepted: February 24, 2021; Published: February 26,2021 
neoplasms. Furthermore, soy isoflavones can increase the amount of estrogen transformed from the active to the sulphated form, which is much less active in human tissues. Genistein causes a down-regulation of the MDM2 oncogene, and this mechanism of action seems very important to explain its antitumor action. Genistein is capable of optimizing the extrarenal synthesis of vitamin D3, which helps to slow down the growth of breast, colon and prostate tumors thanks to its antimitotic action. Finally, soy isoflavones have a powerful antioxidant / anti-radical action, which hinders the pro-tumor cell damage linked to free radicals. Numerous clinical studies and meta-analisys have evaluated the antineoplastic effect of soy isoflavones, generally with very promising results [22-42].

\section{Aloe vera and barbadensis}

It has an antimutagenic action, as, for example, it decreases the mutagenic activity of benzopyrene. This action appears to be due to direct inhibition of liver microsome activation and not to interaction with benzopyrene metabolites and / or DNA repair processes. Furthermore, some substances contained in this drug have cytotoxic, antiproliferative and proapoptotic action. The neoplasms that appear to be most sensitive to this drug are those of the digestive system, lung and skin [43-50].

\section{Camellia sinensis (Green tea)}

The polyphenols of green tea, and in particular the catechins epigallocatechin-3-gallate (EGCG), epigallocatechin (EGC) and epicatechin-3-gallate (ECG) make up 30-40\% of the components of green tea extract and may have anticancer action. It is due to their strong antioxidant action, the stimulation of phase 1 and phase 2 detoxifying enzymes, the inhibition of tumor initiation and promotion markers and the inhibition of cell replication. The anticancer action of green tea has been studied on tumors of the esophagus, skin, mouth, colon, stomach, liver, pancreas, small intestine, bladder, prostate and breast. The main constituents for carrying out this action are polyphenols and in particular EGCG. Green tea hinders cell proliferation, induces apoptosis and stimulates the activity of endogenous detoxifying enzymes. Moreover, it must be said that the results of the in vitro studies are not fully transposable in vivo and that the clinical studies carried out so far have quite contradictory results [51-74].

In addition to the above in a nutshell, phytotherapy can act as a complementary therapy in the neoplastic patient in the following fields of action:

- Stimulation of the body's non-specific immune defenses, with particularly evident effects on neutrophil granulocytes, macrophages, monocytes and NK cells.

- Prebiotic action in the intestine, with improvement of the trophism of the intestinal bacterial flora and consequent improvement of intestinal immunity, which as known is of crucial importance in particular in adults. It can also hinder the depletion of intestinal bacterial flora induced by chemotherapy and radiotherapy.

- A tonic and energizing action on both a psychic and physical level, very useful for fighting the profound asthenia induced by neoplasms and anticancer therapies. In this sense it can also favor the feeding of the neoplastic patient.

- Antiemetic and gastroprotective action, particularly useful in patients receiving anticancer therapy.

- Protective action on the skin against skin damage caused for example by radiotherapy.
- Antioxidant / anti-radical action at the level of the whole organism.

- Action of synergy and enhancement of the effects of some anticancer drugs and radiotherapy.

All these effects are proven by scientific literature, in many cases still limited but susceptible to enormous developments. I therefore think that the fields of action that could be proposed are many and of great scientific interest, obviously always in the context of complementary and / or palliative therapy of the neoplastic patient.

\section{References}

1. Anand, P, Sundaram C, Jhurani S, Kunnumakkara AB, Aggarwal BB (2008) Curcumin and cancer: An "old-age" disease with an "age-old" solution. Cancer Lett 267: 133164. [Crossref]

2. Bayet-Robert M, Kwiatkowski F, Leheurteur M, Gachon F, Planchat E, et al. (2010) Phase I dose escalation trial of docetaxel plus curcumin in patients with advanced and metastatic breast cancer. Cancer Biol Ther 9: 8-14. [Crossref]

3. Irving GR, Iwuji CO, Morgan B, Berry DP, Steward WP, et al. (2015) Combining curcumin (C3-complex, Sabinsa) with standard care FOLFOX chemotherapy in patients with inoperable colorectal cancer (CUFOX): study protocol for a randomized control trial. Trials 16: 110. [Crossref]

4. Yao Q, Ye X, Wang L, Gu J, Fu T, et al. (2013) Protective effect of curcumin on chemotherapy-induced intestinal dysfunction. Int J Clin Exp Pathol 6: 2342-2349. [Crossref]

5. Benzer F, Kandemir FM, Ozkaraca M, Kucukler S, Caglayan C (2018) Curcumin ameliorates doxorubicin-induced cardiotoxicity by abrogation of inflammation, apoptosis, oxidative DNA damage, and protein oxidation in rats. $J$ Biochem $\mathrm{Mol}$ Toxicol 32: [Crossref]

6. Wang Y, Hu PC, Gao FF, Lv JW, Xu S, et al. (2014) The protective effect of curcumin on hepatotoxicity and ultrastructural damage induced by cisplatin. Ultrastruct Pathol 38: 358-362. [Crossref]

7. Ortega-Domínguez B, Aparicio-Trejo OE, García-Arroyo FE, León-Contreras JC, Tapia E, et al. (2017) Curcumin prevents cisplatin-induced renal alterations in mitochondrial bioenergetics and dynamic. Food Chem Toxicol 107: 373-385. [Crossref]

8. Sankrityayan H, Majumdar AS (2016) Curcumin and folic acid abrogated methotrexate induced vascular endothelial dysfunction. Can J Physiol Pharmacol 94: 89-96. [Crossref]

9. Sankrityayan H, Majumdar AS (2016) Curcumin and folic acid abrogated methotrexate induced vascular endothelial dysfunction. Can J Physiol Pharmacol 94: 89-96. [Crossref]

10. Wei Y, Yang P, Cao S, Zhao L (2018) The combination of curcumin and 5-fluorouracil in cancer therapy. Arch Pharm Res 41: 1-13. [Crossref]

11. Devassy JG, Nwachukwu ID, Jones PJ (2015) Curcumin and cancer: Barriers to obtaining a health claim. Nutr Rev 73: 155-165. [Crossref]

12. Larasati YA, Yoneda-Kato N, Nakamae I, Yokoyama T, Meiyanto E, et al. (2018) Curcumin targets multiple enzymes involved in the ROS metabolic pathway to suppress tumor cell growth. Sci Rep 8: 2039. [Crossref]

13. Derosa G, Maffioli P, Simental-Mendía LE, Bo S, Sahebkar A (2016) Effect of curcumin on circulating interleukin-6 concentrations: A systematic review and metaanalysis of randomized controlled trials. Pharmacol Res 111: 394-404. [Crossref]

14. Shamim U, Hanif S, Albanyan A, Beck FW, Bao B, et al. (2012) Resveratrolinduced apoptosis is enhanced in low $\mathrm{pH}$ environments associated with cancer. $J$ Cell Physiol 227: 1493-1500. [Crossref]

15. Mitani T, Ito Y, Harada N, Nakano Y, Inui H, et al. (2014) Resveratrol reduces the hypoxia-induced resistance to doxorubicin in breast cancer cells. J Nutr Sci Vitaminol (Tokyo) 60: 122-128. [Crossref]

16. Sun W, Wang W, Kim J, Keng P, Yang S, et al. (2008) Anti-cancer effect of resveratrol is associated with induction of apoptosis via a mitochondrial pathway alignment. $A d v$ Exp Med Biol 614: 179-186. [Crossref]

17. Kimura Y, Sumiyoshi M (2016) Resveratrol Prevents Tumor Growth and Metastasis by Inhibiting Lymphangiogenesis and M2 Macrophage Activation and Differentiation in Tumor-associated Macrophages. Nutr Cancer 68: 667-678. [Crossref]

18. Casanova F, Quarti J, da Costa DC, Ramos CA, da Silva JL, et al. (2012) Resveratrol chemosensitizes breast cancer cells to melphalan by cell cycle arrest. $J$ Cell Biochem 113: 2586-2596. [Crossref] 
19. Shadfar S, Couch ME, McKinney KA, Weinstein LJ, Yin X, et al. (2011) Oral Resveratrol Therapy Inhibits Cancer-Induced Skeletal Muscle and Cardiac Atrophy In Vivo. Nutr Cancer 63: 749-762. [Crossref]

20. Patel KR, Brown VA, Jones DJ, Britton RG, Hemingway D, et al. (2010) Clinical pharmacology of resveratrol and its metabolites in colorectal cancer patients. Cancer Res 70: 7392-7399. [Crossref]

21. Chow HH, Garland LL, Hsu CH, Vining DR, Chew WM, et al. (2010) Resveratrol modulates drug- and carcinogen-metabolizing enzymes in a healthy volunteer study. Cancer Prev Res (Phila) 3: 1168-1175. [Crossref]

22. Butler LM, Wu AH, Wang R, Koh WP, Yuan JM, et al. (2010) A vegetable-fruitsoy dietary pattern protects against breast cancer among postmenopausal Singapore Chinese women. Am J Clin Nutr 91: 1013-1019. [Crossref]

23. Shimazu T, Inoue M, Sasazuki S, Iwasaki M, Sawada N, et al. (2010) Isoflavone intake and risk of lung cancer: a prospective cohort study in Japan. Am J Clin Nutr 91: 722728. [Crossref]

24. Calveley VL, Jelveh S, Langan A, Mahmood J, Yeung IW, et al. (2010) Genistein can mitigate the effect of radiation on rat lung tissue. Radiat Res 173: 602-611. [Crossref]

25. Dong JY, Qin LQ (2011) Soy isoflavones consumption and risk of breast cancer incidence or recurrence: a meta-analysis of prospective studies. Breast Cancer Res Treat 125: 315-323. [Crossref]

26. Ollberding NJ, Lim U, Wilkens LR, Setiawan VW, Shvetsov YB, et al. (2012) Legume, soy, tofu, and isoflavone intake and endometrial cancer risk in postmenopausal women in the multiethnic cohort study. J Natl Cancer Inst 104: 67-76. [Crossref]

27. Wada K, Nakamura K, Tamai Y, Tsuji M, Kawachi T, et al. (2013) Soy isoflavone intake and breast cancer risk in Japan: From the Takayama study. Int J Cancer 133: 952-960. [Crossref]

28. Li Y, Chen H, Hardy TM, Tollefsbol TO (2013) Epigenetic regulation of multiple tumor-related genes leads to suppression of breast tumorigenesis by dietary genistein. PLoS One 8: e54369. [Crossref]

29. Van Die MD, Bone KM, Williams SG, Pirotta MV (2013) Soy and soy isoflavones in prostate cancer: a systematic review and meta-analysis of randomised controlled trials. BJU Int 113: E119-130. [Crossref]

30. Zhang S, Wang Y, Chen Z, Kim S, Iqbal S, et al. (2013) Genistein enhances the efficacy of cabazitaxel chemotherapy in metastatic castration-resistant prostate cancer cells. Prostate 73: 1681-1689. [Crossref]

31. Hu XJ, Xie MY, Kluxen FM, Diel P (2014) Genistein modulates the anti-tumor activity of cisplatin in MCF-7 breast and HT-29 colon cancer cells. Arch Toxicol 88: 625-635. [Crossref]

32. Suzuki R, Kang Y, Li X, Roife D, Zhang R, et al. (2014) Genistein potentiates the antitumor effect of 5-Fluorouracil by inducing apoptosis and autophagy in human pancreatic cancer cells. Anticancer Res 34: 4685-4692. [Crossref]

33. Carbonel AA (2014) Soybean isoflavones attenuate the expression of genes related to endometrial cancer risk. Climacteric 20: 1-22. [Crossref]

34. Wada K, Tsuji M, Tamura T, Konishi K, Kawachi T, et al. (2015) Soy isoflavone intake and stomach cancer risk in Japan: From the Takayama study. Int J Cancer 137: 885892. [Crossref]

35. Nazim UM, Park SY (2015) Genistein enhances TRAIL-induced cancer cell death via inactivation of autophagic flux Oncol Rep 34: 2692-2698. [Crossref]

36. Shin A, Lee J, Lee J, Park MS, Park JW, et al. (2015) Isoflavone and Soyfood Intake and Colorectal Cancer Risk: A Case-Control Study in Korea. PLoS One 10: e0143228. [Crossref]

37. Zhang M, Wang K, Chen L, Yin B, Song Y, et al. (2016) Is phytoestrogen intake associated with decreased risk of prostate cancer? A systematic review of epidemiological studies based on 17,546 cases. Andrology 4: 745-756. [Crossref]

38. Yu Y, Jing X, Li H, Zhao X, Wang D (2016) Soy isoflavone consumption and colorectal cancer risk: a systematic review and meta-analysis. Sci Rep 6: 25939. [Crossref]

39. Lu D (2017) Meta-analysis of Soy Consumption and Gastrointestinal Cancer Risk. Sci Rep 7: 4048. [Crossref]

40. Namazi N, Saneei P, Larijani B, Esmaillzadeh A (2018) Soy product consumption and the risk of all-cause, cardiovascular and cancer mortality: a systematic review and meta-analysis of cohort studies. Food Funct 9: 2576-2588. [Crossref]
41. Touillaud M, Gelot A, Mesrine S, Bennetau-Pelissero C, Clavel-Chapelon F, et al. (2019) Use of dietary supplements containing soy isoflavones and breast cancer risk among women aged $>50$ y: a prospective study. Am J Clin Nutr 109: 597-605. [Crossref]

42. Liu R, Xu X, Liang C, Chen X, Yu X, et al. (2019) ER $\beta$ modulates genistein's cisplatinenhancing activities in breast cancer MDA-MB-231 cells via P53-independent pathway. Mol Cell Biochem 456: 205-216. [Crossref]

43. Sawada N, Iwasaki M, Yamaji T, Shimazu T, Inoue M, et al. (2020) Soy and isoflavone consumption and subsequent risk of prostate cancer mortality: the Japan Public Health Center-based Prospective Study. Int J Epidemiol 49: 1553-1561. [Crossref]

44. Pecere T, Gazzola MV, Mucignat C, Parolin C, Vecchia FD, et al. (2000) Aloe-emodin is a new type of anticancer agent with selective activity against neuroectodermal tumors. Cancer Res 60: 2800-2804. [Crossref]

45. Kuo PL, Lin TC, Lin CC (2002) The antiproliferative activity of aloe-emodin is through p53-dependent and p21-dependent apoptotic pathway in human hepatoma cell lines. Life Sci 71: 1879-1892. [Crossref]

46. Richerdson J, Smith JE, McIntyre M, Thomas R, Pilkington K (2005) Aloe vera for preventing radiation-induced skin reactions: a systematic literature review. Clin Oncol (R Coll Radiol) 17: 478-484. [Crossref]

47. Yoo EJ, Lee BM (2005) Chemopreventive effects of aloe against genotoxicity induced by benzo[a]pyrene. J Toxicol Environ Health $A$ 68: 1841-1860. [Crossref]

48. Lin ML, Lu YC, Su HL, Lin HT, Lee CC, et al. (2011) Destabilization of CARP mRNAs by aloe-emodin contributes to caspase-8-mediated p53-independent apoptosis of human carcinoma cells. J Cell Biochem 112: 1176-1191. [Crossref]

49. Haddad P, Amouzgar-Hashemi F, Samsami S, Chinichian S, Oghabian MA (2013) Aloe vera for prevention of radiation-induced dermatitis: a self-controlled clinical trial. Curr Oncol 20: e345-e348. [Crossref]

50. Im SA, Kim KH, Kim HS, Lee KH, Shin E, et al. (2014) Processed Aloe vera ge ameliorates cyclophosphamide-induced immunotoxicity. Int J Mol Sci 15: 19342 19354. [Crossref]

51. Ozenver N, Saeed M, Demirezer LÖ, Efferth T (2018) Aloe-emodin as drug candidate for cancer therapy. Oncotarget 9: 17770-17796. [Crossref]

52. Stearns ME, Wang M (2011) Synergistic Effects of the Green Tea Extract Epigallocatechin-3-gallate and Taxane in Eradication of Malignant Human Prostate Tumors. Transl Oncol 4: 147-156. [Crossref]

53. Shimizu M, Adachi S, Masuda M, Kozawa O, Moriwaki H (2011) Cancer chemoprevention with green tea catechins by targeting receptor tyrosine kinases. Mol Nutr Food Res 55: 832-843. [Crossref]

54. Sing MF, Yang WS, Gao S, Gao J, Xiang YB (2011) Epidemiological studies of the association between tea drinking and primary liver cancer: a meta-analysis. Eur $J$ Cancer Prev 20: 157-165. [Crossref]

55. Sasazuki S, Tamakoshi A, Matsuo K, Ito H, Wakai K, et al. (2012) Green Tea Consumption and Gastric Cancer Risk: An Evaluation Based on a Systematic Review of Epidemiologic Evidence Among the Japanese Population. Jpn J Clin Oncol 42: 335346. [Crossref]

56. Montague JA, Butler LM, Wu AH, Genkinger JM, Koh WP, et al. (2012) Green and black tea intake in relation to prostate cancer risk among Singapore Chinese. Cancer Causes Control 23: 1635-1641. [Crossref]

57. Wang ZH, Gao QY, Fang JY (2012) Green tea and incidence of colorectal cancer: evidence from prospective cohort studies. Nutr Cancer 64: 1143-1152. [Crossref]

58. Wu Y, Zhang D, Kang S (2013) Black tea, green tea and risk of breast cancer: an update. Springerplus 2: 240. [Crossref]

59. Gao M, Ma W, Chen XB, Chang ZW, Zhang XD, et al. (2013) Meta-analysis of Green Tea Drinking and the Prevalence of Gynecological Tumors in Women. Asia Pac J Public Health 25: 43S-48S. [Crossref]

60. Wang W, Yang Y, Zhang W, Wu W (2014) Association of tea consumption and the risk of oral cancer: A meta-analysis. Oral Oncol 50: 276-281. [Crossref]

61. Iwasaki M, Mizusawa J, Kasuga Y, Yokoyama S, Onuma H, et al. (2014) Green tea consumption and breast cancer risk in Japanese women: a case-control study. Nutr Cancer 66: 57-67. [Crossref]

62. Kim KC, Lee C (2014) Reversal of Cisplatin resistance by epigallocatechin gallate is mediated by downregulation of axl and tyro 3 expression in human lung cancer cells. Korean J Physiol Pharmacol 18: 61-66. [Crossref] 
63. Lin YW, Hu ZH, Wang X, Mao QQ, Qin J, et al. (2014) Tea consumption and prostate cancer: an updated meta-analysis. World J Surg Oncol 12: 38. [Crossref]

64. Saeed NM, El-Naga RN, El-Bakly WM, Abdel-Rahman HM, Salah ElDin RA, et al. (2015) Epigallocatechin-3-gallate pretreatment attenuates doxorubicin-induced cardiotoxicity in rats: A mechanistic study. Biochem Pharmacol 95: 145-155. [Crossref]

65. Wang P, Henning SM, Heber D, Vadgama JV (2015) Sensitization to docetaxel in prostate cancer cells by green tea and quercetin. J Nutr Biochem 26: 408-415. [Crossref]

66. Je Y (2015) Tea Consumption and Endometrial Cancer Risk: Meta-Analysis of Prospective Cohort Studies. Nutr Cancer 21: 1-6. [Crossref]

67. Liu J, Liu S, Zhou H, Hanson T, Yang L, et al. (2016) Association of green tea consumption with mortality from all-cause, cardiovascular disease and cancer in a Chinese cohort of 165,000 adult men. Eur J Epidemiol 31: 853-865. [Crossref]

68. Jacob SA (2017) The Effect of Green Tea Consumption on Prostate Cancer Risk and Progression: A Systematic Review. Nutr Cancer 69: 353-364. [Crossref]
69. Dhatwalia SK (2018) Role of EGCG in Containing the Progression of Lung Tumorigenesis - A Multistage Targeting Approach. Nutr Cancer 23: 1-16. [Crossref]

70. Negri A, Naponelli V, Rizzi F, Bettuzzi S (2018) Molecular Targets of EpigallocatechinGallate (EGCG): A Special Focus on Signal Transduction and Cancer. Nutrients 10: 1936. [Crossref]

71. Wada K (2019) Green tea intake and colorectal cancer risk in Japan: the Takayama study. Jpn J Clin Oncol [Crossref]

72. Li X, Yu C, Guo Y, Bian Z, Shen Z, Et al. (2019) Association between tea consumption and risk of cancer: a prospective cohort study of 0.5 million Chinese adults. Eur $J$ Epidemiol 34: 753-763. [Crossref]

73. Filippini T, Malavolti M, Borrelli F, Izzo AA, Fairweather-Tait SJ, et al. (2020) Green Tea (Camellia Sinensis) for the Prevention of Cancer. Cochrane Database Syst Rev 3: CD005004. [Crossref]

74. Zhao LG (2020) Tea Drinking and Risk of Cancer Incidence: A Meta-Analysis of Prospective Cohort Studies and Evidence Evaluation. Adv Nutr.

Copyright: ( 2021 Sannia A. This is an open-access article distributed under the terms of the Creative Commons Attribution License, which permits unrestricted use, distribution, and reproduction in any medium, provided the original author and source are credited. 